\title{
Pengaruh Penambahan Gliserin dan Polivinil Alkohol Terhadap Karakteristik Biofoam dari Kulit Singkong dan Daun Angsana
}

\author{
Melysa Putri ${ }^{1}$, Dwi Kemala Putri ${ }^{1}$, Alvernia Putri ${ }^{1}$ \\ ${ }^{1}$ Politeknik ATI Padang, Jl. Bungo Pasang-Tabing, Padang, 25171, Indonesia
}

\section{ARTICLE INFORMATION}

Received: June 05, 2021

Revised: June 26, 2021

Available online: June 30, 2021

\section{KEYWORDS}

Angsana Leaves, Biofoam, Cassava Peel, Glycerin, Polyvinyl Alcohol

\section{CORRESPONDENCE}

Name: Melysa Putri

E-mail: melysaputri@poltekatipdg.ac.id

\begin{abstract}
Styrofoam is a petroleum-based and synthetic polymer that is only used once. To reduce waste and environmental damage as well as health problems, this study aims to make Biofoam from cassava peel and angsana leaves using a combination of extrusion and baking methods. In this study, glycerin and polyvinyl alcohol were also added with volume variations, 10: 30 (sample 1), $20: 20$ (sample 2), and 30: 10 (sample 3) $\mathrm{mL}$ to improve the physical properties of Biofoam. The physical characteristics observed were color, water content using the gravimetric method, and water absorption capacity of ABNT NBR NM ISO 535. Sample 1 and sample 2 were lighter in color than sample 3. The lowest water content value was found in sample 2, while sample 2 was has the ability to absorb less water is sample 3 .
\end{abstract}

\section{PENDAHULUAN}

Styrofoam sering digunakan sebagai bungkusan makanan di restauran atau penjual kaki lima karena kepraktisannya. Akan tetapi, penggunaan styrofoam dapat menimbulkan bahaya bagi kesehatan maupun lingkungan. Hal ini disebabkan karena styrofoam terdiri dari $90-95 \%$ polistirena yang dapat menghasilkan gas berbahaya seperti stiren, poliaromatik hidrokarbon, hidrokloroflorokarbon (HCFC), dan karbon monoksida apabila dibakar. Menurut The Environmental Protection Agency (EPA) Amerika, styrofoam menghasilkan limbah sekitar 2,6 juta ton dan merupakan penghasil limbah ke5 terbesar di dunia pada proses pembuatannya [1], [2].

Untuk mengurangi limbah tersebut, beberapa peneliti mencoba membuat Biofoam. Komponen yang paling penting dalam pembuatan Biofoam adalah pati dan serat yang berfungsi untuk memperkuat struktur. Kandungan pati sangat penting dalam menentukan karakteristik fisikokimia dari Biofoam yang dihasilkan dan juga karena pati memiliki sifat biodegrabilitas yang tinggi, murah. Menurut Standard European Union, Biofoam ini akan terdekomposisi menjadi karbohidrat, air, dan substansi humus dalam rentang waktu $6-9$ bulan. Sehingga dapat mengurangi dampak penggunaan styrofoam dan ikut serta dalam memanfaatkan limbah di sekitar kita [1], [3], [4].

Akan tetapi, Biofoam yang terbentuk dari pati murni memberikan sifat fisika dan sifat mekanik yang kurang baik serta mudah larut dalam air. Untuk itu perlu dilakukan modifikasi dengan penambahan zat pemlastis, polimer, serat, dan beberapa tambahan lainnya. Zat pemlastis yang paling banyak digunakan adalah gliserol. Penambahan gliserol dapat memperbaiki sifat fisik, sifat mekanik, dan melindungi plastik dari mikroorganisme yang dapat merusak plastik. Untuk dapat meningkatkan kualits produk yang dihasilkan terutama dalam mengurangi sifatnya dalam menyerap air, maka perlu ditambahkan polivinil alcohol [1], [4], [5].

Beberapa penelitian telah dilakukan dalam mencari dan menentukan kandungan pati dan serat yang baik dalam membuat Biofoam. Salah satunya adalah pemanfaatan kulit pisang dan daun kamboja kering dengan penambahan gliserin, asam asetat, dan campuran lainnya 
menghasilkan Biofoam berpori besar dan daya serap airnya tinggi karena rendahnya kandungan pati dan pencetakan hanya menggunakan teflon pada oven 250 ${ }^{\circ} \mathrm{C}$. Kombinasi sorgum dengan daun mangga kering menghasilkan Biofoam dengan daya serap airnya rendah karena menggunakan PVA dan gliserin yang mereduksi penyerapan air dan meningkatkan hidrofobisitas Biofoam. Biofoam yang berbahan dasar pati, protein, dan kitosan dengan penambahan variasi magnesium stearat melalui metode baking proses menghasilkan Biofoam dengan tingkat penyerapan air dan biodegradablitas yang rendah [2], [6], [7].

Bangkit pada tahun 2020 telah membuat Biofoam dari pati biji durian dan nanoserat selulosa ampas teh dengan metode pemanggangan dengan menggunakan variasi PVA $10 \%, 20 \%$, dan $30 \%$. Proses pembuatan Biofoam dilakukan dengan menggunakan oven pada suhu $80{ }^{\circ} \mathrm{C}$ selama 60 menit. Dari hasil penelitiannya, sampel yang diberikan PVA $30 \%$. Pemanfaatan limbah kulit singkong menjadi Biofoam telah pernah dilakukan oleh peneliti lain di tahun 2019. Peneliti memvariasikan waktu dan suhu proses thermopressing dalam pengembangan Biofoam berbasis tapioka dan $\alpha$-selulosa kulit singkong. Variasi suhu yang digunakan adalah 150, 160, 170, dan $175^{\circ} \mathrm{C}$, sedangkan variasi waktu yang digunakan adalah 30, 40, 50, dan 60 menit. Berdasarkan penelitian tersebut kondisi operasional yang terbaik adalah suhu $175{ }^{\circ} \mathrm{C}$ selama 60 menit. Pada tahun 2016, Irma dan kawankawan membuat Biofoam dengan pengaruh penambahan kitosan dan gelatin pada bahan baku pati biji nangka. Selain itu, Nurfitasari kulit singkong menghasilkan Biofoam yang berwarna coklat dan rapuh karena tidak menggunakan PVA. Oleh karena itu, kami mencoba membuat Biofoam dari kombinasi kulit singkong dengan daun angsana dengan penambahan polivinil alkohol. Selain itu, penelitian ini juga dilatarbelakangi oleh belum adanya penggunaan daun angsana sebagai sumber serat dalam pembuatan Biofoam [4], [8], [9].

\section{METODOLOGI}

Penelitian ini dilakukan di laboratorium Operasi Teknik Kimia dan Laboratorium Dasar, Politeknik ATI Padang, Bungo Pasang, Tabing. Untuk menunjang pelaksanaan penelitian ini, maka dibutuhkan beberapa peralatan dan bahan antara lain: kulit singkong dan daun angsana sebagai bahan baku, gliserin, polivinil alkohol, magnesium stearat, aquadest, beberapa peralatan gelas, magnetic stirrer dan magnetic barr, pemberat, saringan, termometer, blender, dan oven.

\section{Pembuatan Tepung Kulit Singkong dan Serat dari Daun Angsana}

Untuk membuat tepung dari kulit singkong, bahan dasar yang digunakan adalah kulit singkong bagian dalam. Kulit singkong tersebut dibersihkan terlebih dahulu dengan menggunakan air. Kulit singkong tersebut kemudian diblender dan dikeringkan. Pati yang telah kering diblender dan diayak dengan ayakan 60 mesh. Sedangkan untuk mengambil serat dari daun angsana, hal yang dilakukan terlebih dahulu adalah mencuci daun tersebut dengan air. Selanjutnya direbus selama 1 jam kemudian dikeringkan dan diblender. Tepung yang dihasilkan diayak dengan ayakan 60 mesh [3], [9].

\section{Pembuatan Biofoam}

Pembuatan Biofoam dilakukan dengan menggabungkan metode ekstrusi yang dikembangkan oleh Nurfitasari dan baking process. Gelas piala $500 \mathrm{~mL}$ disiapkan sebanyak 3 buah. Sebanyak 34,3 gram pati kulit singkong ditambahkan dengan 0,7 gram serat daun angsana dicampurkan dengan 0,35 gram magnesium stearat dalam masing-masing gelas piala. Selanjutnya gliserin dan PVA ditambahkan ke dalam masing-masing gelas piala dengan variasi $10 \mathrm{~mL}$ gliserin : $30 \mathrm{~mL}$ PVA (sampel 1), $20 \mathrm{~mL}$ gliserin : $20 \mathrm{~mL}$ PVA (sampel 2), dan $30 \mathrm{~mL}$ gliserin : $10 \mathrm{~mL}$ PVA (sampel 3) sambil dipanaskan. Campuran tersebut dihomogenkan hingga terbentuk seperti adonan kue. Adonan dicetak dan dimasukkan ke dalam oven selama 1 jam pada suhu $170{ }^{\circ} \mathrm{C}$. Kemudian didinginkan pada suhu ruang selama 3 hari. dilakukan uji karakteristik Biofoam [3], [9], [10].

\section{Uji Warna}

Biofoam yang telah didinginkan pada suhu kamar selama 3 hari, diamati warnanya.

\section{Uji Kadar Air}

Analisis kadar air dilakukan dengan menggabungkan metode yang dilakukan oleh Bangkit (2020) dengan Nurfitasari (2018). Biofoam yang telah dihasilkan ditmbang dan dioven selama 5 menit pada suhu $100{ }^{\circ} \mathrm{C}$. Kemudian didinginkan selama 10 menit dan ditimbang. Prosedur yang sama kembali dilakukan hingga didapatkan berat konstan [8], [9].

\section{Daya Serap Air}

Sampel dari ketiga variasi dipotong-potong, kemudian ditimbang. Sampel tersebut kemudian dicelupkan ke dalam gelas piala yang berisi air dengan variasi waktu perendaman 2, 4, 6, dan 8 menit. Setelah direndam, sampel diangkat dan dikeringkan. Selanjutnya sampel ditimbang dan dihitung daya serap airnya dengan rumus:

DSA $(\%)=($ berat sampel setelah dicelup-berat sampel awal) /berat sampel awal x 100\% [11] 


\section{HASIL DAN PEMBAHASAN}

\section{Warna}

Biofoam dibuat dengan memanfaatkan kemampuan pati untuk mengembang karena adanya pengaruh panas dan gesekan selama proses ekstrusi. Proses ekstrusi umumnya menggunakan suhu tinggi. Panas yang dihasilkan selama proses ekstrusi akan menyebabkan pati dan bahan campuran lainnya mengalami perubahan fisikokimia. Berdasarkan Gambar 1, dapat dilihat sampel 3 dan sampel 2 memiliki warna yang lebih bagus daripada sampel 1.

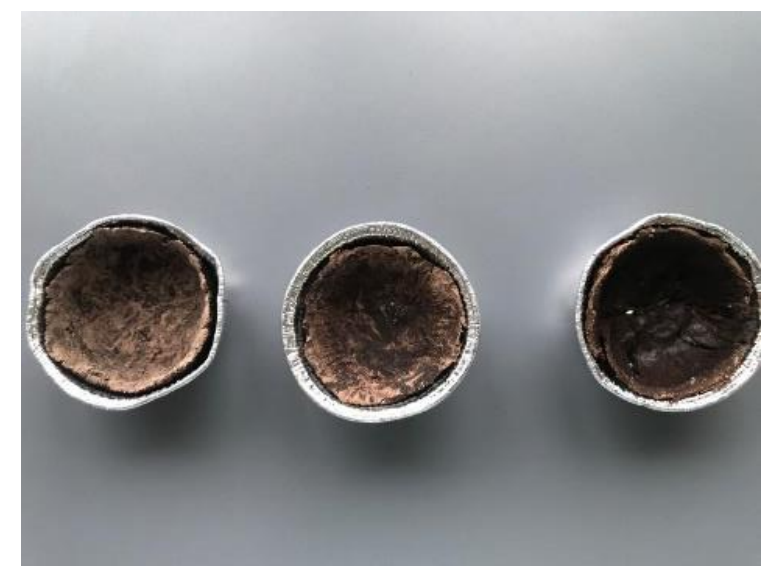

Gambar 1. Biofoam dari kulit singkong dan daun angsana, dari kiri ke kanan sampel 3, sampel 2, dan sampel 1

\section{Analisis Kadar Air}

Analisis kadar air dilakukan untuk mengetahui ketahanan Biofoam terhadap penyerapan air. Hal ini disebabkan karena pati sangat rentan terhadap air karena adanya ikatan hidrogen pada pati, sehingga dapat menurunkan sifat fungsional dari foam. Kadar air pada adonan Biofoam merupakan blowing agent yang dapat meningkatkan pengembangan adonan Biofoam untuk menghasilkan struktur berongga. Adonan yang terlalu encer akan menyebabkan struktur Biofoam banyak rongga, dinding yang tipis dan daya serap yang tinggi [12].

\section{Pengaruh Penambahan Gliserin dan PVA Terhadap Kadar Air Biofoam}

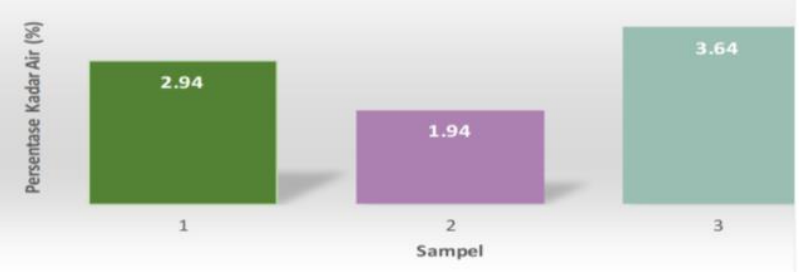

Gambar 2. Grafik pengaruh penambahn gliserin dan PVA terhadap kadar air Biofoam

Dari Gambar 2 dapat dilihat bahwa sampel 3 memiliki kadar air yang paling tinggi daripada sampel lainnya.
Sampel 3 terdiri dari $30 \mathrm{~mL}$ gliserin dan $10 \mathrm{~mL}$ PVA. Adanya penambahan gliserin terhadap sampel dapat menurunkan ketahanan sampel terhadap air. Hal ini disebabkan karena adanya gugus hidroksil pada gliserin yang bersifat hidrofilik. Sehingga meregangkan ikatan antar molekul amilosa yang memungkinkan terjadinya celah dan air dapat masuk [13].

Sedangkan sampel 1 dan sampel 2 memiliki kadar air yang lebih rendah daripada sampel 3. Hal ini disebabkan karena penambahan PVA dapat meningkatkan fleksibelitas dan ketahanan Biofoam terhadap air. Hal ini disebabkan oleh sifat hidrofobisitas dari PVA. Jika dibandingkan dengan kadar air styrofoam yang ada saat ini yaitu sebesar $1,11 \%$, maka dapat dikatakan bahwa sampel 2 lebih mendekati nilai kadar air dari Styrofoam [14], [15].

\section{Daya Serap Air}

Berdasarkan Gambar 3, dapat dilihat bahwa daya serap masing-masing sampel air tidak terlalu jauh berbeda. Akan tetapi, sampel 3 mimiliki daya serap air yang lebih stabil dibanding sampel lainnya. Hal ini disebabkan karena sampel 3 mengandung PVA lebih banyak daripada sampel lainnya. Penambahan PVA dapat menurunkan penyerapan air dan meningkatkan hidrofobisitas dari Biofoam. Penambahan PVA juga dapat meningkatkan kualitas dari Biofoam yang diproduksi terutama dalam mengurangi sifat menyerap air, karena mengurangi rongga udara yang terbentuk [1], [2].

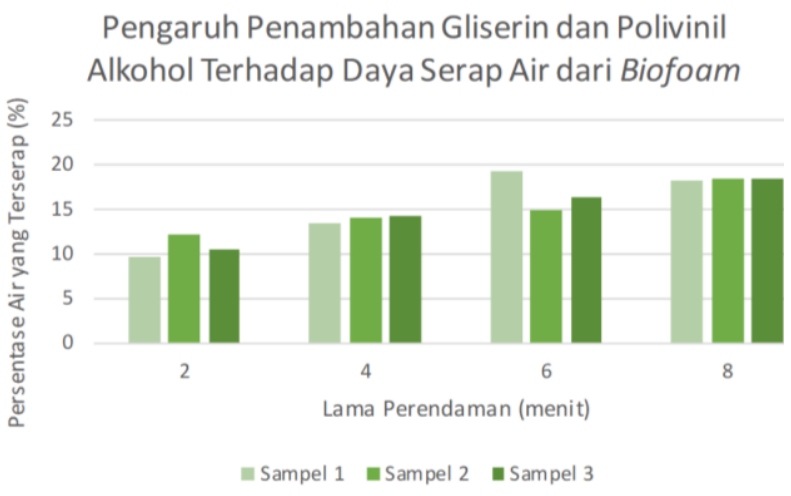

Gambar 3. Grafik pengaruh penambahan gliserin dan PVA terhadap daya serap air Biofoam

\section{KESIMPULAN}

Pati kulit singkong dan serat daun angsana dapat digunakan sebagai bahan baku pembuatan Biofoam. Berdasarkan warna yang dihasilkan, sampel 1 dan sampel 2 memiliki warna yang lebih terang daripada sampel 3. Biofoam dengan nilai kadar air paling rendah adalah sampel 2 yang mengandung gliserin dan PVA dengan jumlah yang sama yaitu $20 \mathrm{~mL}$. Sedangkan untuk 
kemampuan daya serap airnya, sampel 3 lebih baik daripada sampel lainnya, karena sampel 3 mengandung PVA lebih banyak daripada sampel lain. Oleh sebab itu perlu dilakukan penelitian lebih lanjut dengan menggunakan metode lain untuk pembuatan Biofoam dan variasi lain sehingga didapatkan Biofoam dengan kualitas yang lebih baik.

\section{DAFTAR PUTAKA}

[1] C. Irawan, J. Ahmad Yani Km, and K. Selatan, "Biodegradable Foam dari Bonggol Pisang dan Ubi Nagara sebagai Kemasan Makanan yang Ramah Lingkungan," Chairul Irawan, pp. 33-42, 2018.

[2] S. R. Adiyar, N. Kadek, A. Kusuma, and S. R. Dewanti, "Effect of Composition on Physical Properties of Biofoam from the Combination of Sorghum and Dried Mango Leaves," vol. 3, no. 7, pp. 20-22, 2019.

[3] Pamilia Coniwanti, Roosdiana Mu'in, Hendra Wijaya Saputra, M. Andre R.A., and Robinsyah, "Pengaruh konsentrasi $\mathrm{NaOH}$ serta rasio serat daun nanas dan ampas tebu pada pembuatan Biofoam," Jurnal Teknik Kimia, vol. 24, no. 1, pp. 1-7, 2018, doi: 10.36706/jtk.v24i1.411.

[4] M. P. Paramita, P. Studi, T. Kimia, F. Teknik, and U. M. Surakarta, "Pengaruh Variasi Waktu Dan Suhu Proses Thermopressing Pada Pengembangan Biodegradable Foam Berbasis Tapioka Dan A Selulosa Kulit Singkong," 2019.

[5] I. I. Sari, "Pemanfaatan Tepung Kulit Singkong (Manihot utilissima) Untuk Pembuatan Plastik Ramah Lingkungan (Biodegradable) Dengan Penambahan Gliserol Dari Minyak Jelantah,” 2015.

[6] I. N. W. Nanik Hendrawati, Anna Rubi Sofiana, "Pengaruh Penambahan Magnesium Stearat Dan Jenis Protein Pada Pembuatan Biodegradable Foam Dengan Metode Baking Process," Jurnal Bahan Alam Terbarukan, vol. 4, no. 2, pp. 34-39, 2016, doi: 10.15294/jbat.v4i2.4166.

[7] E. Rusliana, M. Saleh, and M. Assagaf, "Penentuan Kodisi Proses Terbaik Pembuatan Biofoam Dari Limbah Pertanian Lokal Maluku Utara," no. November, pp. 10-13, 2014.

[8] B. K. S. Sipahutar, "Pembuatan biodegradable foam dari pati biji durian (Durio zibethinus) dan nanoserat selulosa ampas teh (Camellia sinensis) dengan proses pemanggangan skripsi," 2020.

[9] I. Nurfitasari, "Pengaruh Penambahan Kitosan Dan Gelatin Terhadap Kualitas Biodegradable Foam Berbahan Baku Pati Biji Nangka (Artocarpus heterophyllus)," 2018.

[10] Y. Ruscahyani, "Pemanfaatan Kulit Jagung Sebagai Bahan Pembuatan Biodegradable Foam,” 2020.

[11] Etikaningrum, Joko Hermanianto, Evi Savitri Iriani, Rizal Syarief, and Asep Wawan Permana, "Pengaruh Penambahan Berbagai Modifikasi Serat Tandankosong Sawit Pada Sifat Fungsional Biodegradable Foam," Jurnal Penelitian Pascapanen Pertanian, vol. 3, no. 3, pp. 146-155, Dec. 2016.
[12] S. Bahri, Fitriani, and Jalaluddin, "Pembuatan Biofoam Dari Ampas Tebu Dan Tepung Maizena," Jurnal Teknologi Kimia Unimal, vol. 1, no. Mei, pp. 24-32, 2021.

[13] S. Purnavita, D. Y. Subandriyo, and A. Anggraeni, "Penambahan Gliserol terhadap Karakteristik Bioplastik dari Komposit Pati Aren dan Glukomanan," METANA, vol. 16, no. 1, pp. 19-25, May 2020, doi: 10.14710/metana.v16i1.29977.

[14] N. Kaisangsri, O. Kerdchoechuen, and N. Laohakunjit, "Biodegradable foam tray from cassava starch blended with natural fiber and chitosan," Industrial Crops and Products, vol. 37, no. 1, pp. 542-546, 2012, doi: 10.1016/j.indcrop.2011.07.034.

[15] P. R. Salgado, V. C. Schmidt, S. E. Molina, and A. N. Mauri, "Biodegradable foams based on cassava starch, sunflower proteins and cellulose fibers obtained by a baking process," vol. 85 , pp. 435-443, 2008, doi: 10.1016/j.jfoodeng.2007.08.005. 